\title{
PARTISIPASI MASYARAKAT DALAM PERENCANAAN TATA RUANG DAERAH UNTUK PEMBANGUNAN WILAYAH KOTA PADANG
}

\author{
Rika Despica \\ Program Studi Pendidikan Geografi STKIP PGRI Sumatera Barat \\ despicharekha@yahoo.com
}

\begin{abstract}
Climate and good performance in the construction needs to be executed, the characteristic is community participation, transparency, responsiveness and accountability. If this does not work together it will be a bottleneck in the development. With reference to the MPR IV / MPR / 2000 on recommendations in the Implementation of Regional Autonomy Policy, then the provision of opportunity for the public to actively participate in the implementation of development processes, including in the process of spatial planning. To realize the true public participation should be pursued. So cooperation with relevant parties such as universities, non-governmental organizations (NGOs), community leaders, parliamentarians, and other stakeholders need to be synergized. Strategies undertaken to improve the role of the community can be done by: 1) increasing awareness (Awareness Raising), 2) Advocacy Policy (Policy Advocacy), 3) Development Institutions (Institution Building), 4) Capacity (Capacity Building). Thus the community involvement in spatial planning becomes particularly relevant in the context of creating its territory, namely the layout in the public interest and create a beautiful environment.
\end{abstract}

\begin{abstract}
Abstrak
Iklim dan kinerja yang baik dalam pembangunan perlu dijalankan, karakteristiknya adalah partisipasi masyarakat, transparasi, responsif dan akuntabilitas. Jika ini tidak bersinergi maka akan menjadi hambatan dalam pembangunan. Dengan merujuk pada TAP MPR IV/MPR/2000 tentang rekomendasi Kebijakan Dalam Penyelenggaraan Otonomi Daerah, maka pemberian kesempatan kepada masyarakat untuk berperan aktif dalam berbagai proses penyelenggaraan pembangunan, termasuk didalamnya dalam proses penataan ruang. Untuk mewujudkan partisipasi masyarakat yang sesungguhnya harus diupayakan. Maka kerjasama dengan pihak-pihak terkait seperti perguruan tinggi, lembaga swadaya masyarakat (ornop), tokoh masyarakat, dewan perwakilan rakyat, dan pihak-pihak terkait lainnya perlu disinergikan. Strategi yang dilakukan untuk meningkatkan peran masyarakat dapat dilakukan dengan cara : 1)peningkatan Kesadaran( Awareness Raising ), 2) Advokasi Kebijakan ( Policy Advocacy ), 3) Pengembangan Institusi ( Institution Building ), 4) Pengembangan Kapasitas ( Capacity Building ). Dengan demikian pelibatan masyarakat dalam penataan ruang menjadi sangat relevan dalam rangka menciptakan wilayahnya, yaitu tata ruang yang mengutamakan kepentingan masyarakat dan menciptakan lingkungan yang asri.

Kata Kunci: Partisipasi, Tata Ruang, Pembangunan Wilayah
\end{abstract}

\section{PENDAHULUAN}

Kebijakan sentralisasi pada masa lalu membuat ketergantungan daerahdaerah kepada pusat semakin tinggi dan nyaris mematikan kreatifitas masyarakat beserta seluruh perangkat Pemerintah di daerah. Sementara itu dalam era desentralisasi, partisipasi masyarakat dan azas keterbukaan cenderung untuk dijadikan pedoman dengan asumsi bahwa pelaksanaan prinsip tersebut akan menghasilkan kebijakan yang sesuai dengan kebutuhan masyarakat. Dengan kata 
lain, terdapat rasa memiliki masyarakat terhadap kebijakan yang ditetapkan dan muncul komitmen untuk melaksanakannya sehingga pembangunan yang berkelanjutan dapat diwujudkan.

Pada posisi lain dengan diberlakukannya Undang-undang Otonomi Daerah, telah memberikan legitimasi untuk menyerahkan kewenangan dalam proses penyelenggaraan penataan ruang kepada daerah. Konsekuensi dari kondisi tersebut antara lain adalah memberikan kemungkinan banyaknya Kabupaten/Kota yang lebih memikirkan kepentingannya sendiri, tanpa memikirkan sinergi dalam perencanaan tata ruang dan pelaksanaan pembangunan dengan Kabupaten/Kota lainnya untuk sekedar mengejar targetnya dalam lingkup "kacamata" masingmasing.

Untuk mensinergikan kepentingan masing-masing Kabupaten/Kota diperlukan satu dokumen produk penataan ruang yang bisa dijadikan pedoman untuk menangani berbagai masalah lokal, lintas wilayah, dan yang mampu memperkecil kesenjangan antar wilayah yang disusun dengan mengutamakan peran masyarakat secara intensif. Pada akhirnya, penataan ruang diharapkan dapat mendorong pengembangan wilayah dalam rangka meningkatkan kualitas hidup masyarakat (city as engine of economic growth) yang berkeadilan sosial (social justice) dalam lingkungan hidup yang lestari (environmentaly sound) dan berkesinambungan (sustainability sound) melalui penataan ruang. Dalam rangka menerapkan penataan ruang untuk pada akhirnya mewujudkan pengembangan wilayah seperti yang diharapkan, maka terdapat paradigma yang harus dikembangkan berdasarkan UU No.22/1999)/(UU 32/2004) sebagai berikut:

a. Otonomi daerah mengatur kewenangan Pemerintah Daerah dalam pembangunan Globalisasi

b. Pembangunan wilayah tidak terlepas dari pembangunan dunia, investor akan menanamkan modalnya di daerah yang memiliki kondisi politik yang stabil dan didukung sumberdaya yang memadai

c. Pemberdayaan masyarakat

d. Pendekatan pemberdayaan masyarakat merupakan tuntutan yang harus dipenuhi Good Governance 
Iklim dan kinerja yang baik dalam pembangunan perlu dijalankan, karakteristiknya adalah partisipasi masyarakat, transparasi, responsif dan akuntabilitas. Konsepsi peran serta masyarakat, telah direncanaan oleh berbagai pihak yang berkeinginan menetapkannya sejak tahun 80 -an, tetapi secara formal baru terwujud konsepsinya di tahun 1992 melalui pengundangan UU No. 24 Tahun 1992 tentang Penataan Ruang yang di sahkan pada tanggal 13 Oktober 1992. Hal ini juga sebagai upaya mengantisipasi dan menjaga kesinambungan pembangunan. Selanjutnya diikuti oleh Peraturan Pemerintah , pada tanggal 3 Desember 1996, yaitu PP No.69 Tahun 1996 tentang Pelaksanaan Hak dan Kewajiban, serta Bentuk dan Tata Cara Peran Serta Masyarakat dalam Penataan Ruang.

Disamping itu pemerintah telah mempersiapkan Peraturan Menteri Dalam Negeri No. 9 Tahun 1998 tentang Tatacara Peranserta Masyarakat Dalam Proses Perencanaan Tata Ruang di Daerah. Dalam perundangan tersebut di amanatkan bahwa untuk penyelenggaraan penataan ruang dilaksanakan oleh Pemerintah dengan mengikutsertakan peran serta masyarakat. Peran dan keikutsertaan masyarakat dalam melaksanakan dan mengamankan aturan tersebut amat sangat penting artinya karena hasilnya akan dinikmati kembali oleh masyarakat di wilayahnya.

Selanjutnya dengan merujuk pada TAP MPR IV/MPR/2000 tentang rekomendasi Kebijakan Dalam Penyelenggaraan Otonomi Daerah yaitu “peningkatan pelayanan publik dan pengembangan kreatifitas masyarakat serta aparatur pemerintahan di daerah" terlihat jelas pemberian kesempatan kepada masyarakat untuk berperan aktif dalam berbagai proses penyelenggaraan pembangunan, termasuk didalamnya dalam proses penataan ruang. Semangat tersebut sejalan dengan bunyi pasal 12 UU No 24 Tahun 1992 bahwa "Penataan Ruang dilakukan oleh Pemerintah dan Masyarakat" . Prinsip tersebut seiring dengan Peraturan Pemerintah No 69 Tahun 1996 yang mengedepankan Pemerintah sebagai fasilitator dan masyarakat sebagai pelaku atau stakeholder utama pembangunan.

PP No. 69 Tahun 1996 tentang “ Pelaksanaan hak dan kewajiban, serta bentuk dan tata cara peran serta masyarakat dalam Penataan Ruang " diatur hal-hal yang berkaitan dengan pelaksanaan hak dan kewajiban masyarakat, Bentuk Peran 
Serta Masyarakat, Tata Cara Peran Serta Masyarakat dan Pembinaan Peran Serta Masyarakat diatur berdasar tingkatan hirarki Pemerintahan dari tingkat Nasional, tingkat Propinsi dan tingkat Kabupaten/Kota. Dalam PP ini diatur secara rinci pula hak masyarakat dalam proses perencanaan, pemanfaatan dan pengendalian tata ruang. Tidak hanya hak, tetapi diatur pula kewajiban masyarakat dalam proses Penataan ruang

Metode yang dipakai adalah metode survei dan wawancara dengan para pakar perencanaan daeah yaitu dinas tata ruang daerah, bapeda dan wali kota padang yang membuat kebijakan daerah. Jenis peneliian ini adalah kualitatif. Menurut Sugiyono (2010) mengatakan jenis peneitian kulitatif mendeskripsikan situasi dan apa adanya sesuai engan variabel yang diteliti.

\section{PEMBAHASAN}

\section{Hambatan dalam Pelaksanaan Tataruang}

Undang-Undang nomor 24 tahun 1992 menyebutkan bahwa " ruang adalah wadah yang meliputi ruang daratan, ruang lautan dan ruang udara sebagai satu kesatuan wilayah, tempat manusia dan makhluk lainnya hidup dan melakukan kegiatan serta memelihara kelangsungan hidupnya". Selanjutnya, tata ruang adalah wujud struktural dan pola pemanfaatan ruang, baik direncanakan maupun tidak. Pengertian penataan ruang adalah proses perencanaan tata ruang, pemanfaatan ruang, dan pengendalian pemanfaatan ruang termasuk didalamnya penataan ruang kota. Beberapa persoalan dalam penataan ruang adalah:

1) Kebijakan Pemerintah yang tidak sepenuhnya berorientasi kepada masyarakat, sehingga masyarakat tidak terlibat langsung dalam pembangunan.

2) Tidak terbukanya para pelaku pembangunan dalam menyelenggarakan proses penataan ruang (gap feeling) yang menganggap masyarakat sekedar obyek pembangunan.

3) Rendahnya upaya-upaya pemerintah dalam memberikan informasi tentang akuntabilitas dari program penataan ruang yang diselenggarakan, sehingga masyarakat merasa pembangunan yang dilaksanakan tidak memperhatikan aspirasinya.

4) Walaupun pengertian partisipasi masyarakat sudah menjadi kepentingan 
bersama (common interest), akan tetapi dalam prakteknya masih terdapat pemahaman yang tidak sama. Hal ini ditunjukkan dimana Pemerintah sudah melakukan sosialisasi dan konsultasi dengan masyarakat, akan tetapi masyarakat merasa tidak cukup hanya dengan proses tersebut. Jadi semua proses keputusan yang diambil harus melibatkan masyarakat.

5) Tidak optimalnya kemitraan atau sinergi antara swasta dan masyarakat dalam penyelenggaraan Penataan ruang.

6) Persoalan yang dihadapi dalam perencanan partisipatif saat ini antara lain panjangnya proses pengambilan keputusan, Jarak antara penyampaian aspirasi hingga jadi keputusan relative jauh.

UU 32/2004 (UU No. 22 Tahun 1999 dan PP No. 25 Tahun 2000) tentang Otonomi Daerah maka telah menggeser pemahaman dan pengertian banyak pihak tentang usaha pemanfaatan sumber daya alam, terutama asset yang selama ini diangap untuk kepentingan Pemerintahan Pusat dengan segala perizinan dan aturan yang menimbulkan perubahan kewenangan. Perubahan sebagai tanggapan dari ketidak adilan selama ini, seperti perubahan dalam pengelolaan sumber daya alam yang tidak diikuti oleh aturan yang memadai serta tidak diikuti oleh batasan yang jelas dalam menjaga keseimbangan fungsi Regional atau Nasional. Meskipun di dalam UU tersebut desa juga dinyatakan sebagai daerah otonom, namun tidak memiliki kewenangan yang jelas. Dengan kata lain, sebagian besar kebijakan publik, paling rendah masih diputuskan di tingkat kabupaten. Padahal, mungkin masalah yang diputuskan sesunggguhnya cukup diselesaikan di tingkat local/desa. Jauhnya rentang pengambilan keputusan tersebut merupakan potensi terjadinya deviasi, baik yang pada gilirannya menyebabkan banyak kebijakan publik yang tidak sesuai dengan aspirasi masyarakat.

Berdasar persoalan-persoalan tersebut, upaya keras untuk mewujudkan partisipasi masyarakat yang sesungguhnya harus diupayakan. Maka kerjasama dengan pihak-pihak terkait seperti perguruan tinggi, lembaga swadaya masyarakat (ornop), tokoh masyarakat, dewan perwakilan rakyat, dan pihak-pihak terkait lainnya perlu disinergikan. 


\section{Upaya Pelibatan Masyarakat untuk Berpartisipasi dalam Tata Ruang}

Mengingat partisipasi adalah salah satu elemen penting dalam governance maka untuk mendorong terciptanya good governance, banyak organisasi memilih isu partisipasi sebagai strategi awal mewujudkan good governance. Strategi yang diambil organisasi civil society umumnya dilandasi analisis situsasi yang mengemukakan adanya tiga hambatan utama menuju partisipasi yang baik (Hetifah. 2000), yaitu:

1) Hambatan structural yang membuat iklim atau lingkungan menjadi kurang kondusif untuk terjadinya partisipasi. Di antaranya adalah kurangnya kesadaran berbagai pihak akan pentingnya partisipasi serta kebijakan maupun aturan yang kurang mendukung partisipasi termasuk kebijakan desentralisasi fiskal.

2) Hambatan internal masyarakat sendiri, diantaranya kurang inisiatif, tidak terorganisir dan tidak memiliki kapasitas memadai untuk terlibat secara produktif dalam proses pengambilan keputusan. Hal ini terjadi antara lain akibat kurangnya informasi.

3) Hambatan akibat kurang terkuasainya metode dan teknik-teknik partisipasi.

Pelibatan masyarakat dalam penataan ruang untuk mendukung pembangunan wilayah, maka prinsip dasar yang perlu diperankan oleh pelaksana pembangunan adalah sebagai berikut:

a. Menempatkan masyarakat sebagai pelaku yang sangat menentukan dalam proses penataan ruang

b. Memposisikan pemerintah sebagai fasilitator dalam proses penataan ruang

c. Menghormati hak yang dimiliki masyarakat serta menghargai kearifan lokal dan keberagaman sosial budayanya

d. Menjunjung tinggi keterbukaan dengan semangat tetap menegakkan etika dan moral

e. Memperhatikan perkembangan teknologi dan profesional. 
Prinsip-prinsip dasar tersebut dimaksudkan agar masyarakat sebagai pihak yang paling terkena akibat dari penataan ruang harus dilindungi dari berbagai tekanan dan paksaan pembangunan yang dilegitimasi oleh birokrasi yang sering tidak dipahaminya. Masyarakat juga bagian dari Rakyat Indonesia yang sudah sepatutnya mendapat perlindungan HAM yang dapat dirumuskan dalam perencanaan tata ruang, seperti hak memiliki rasa aman terhadap keberlanjutan ekonomi, hak untuk mendapatkan pelayanan kesehatan, pendidikan, hak untuk mendapatkan rasa aman terhadap bencana dan lainnya.

\section{Strategi Peningkatan Partisipasi Masyarakat dalam Pembangunan wilayah}

Strategi yang perlu dilakukan dalam mendorong proses partisipasi menuju good government di kota padang adalah:

a. Peningkatan Kesadaran (Awareness Raising)

1) Memperkaya konsep-konsep pembangungan partisipatoris dalam pengembilan keputusan publik.

2) Mendorong kesadaran eksekutif dan legislatitif agar lebih membuka diri terhadap partisipasi masyarakat/warga. Dengan cara seminar, workshop dan pelatihan untuk mengangkat aspek partisipasi ke dalam proses pembangunan.

3) Mendorong permintaan yang lebih besar untuk partisipasi dan akuntabilitas dengan meningkatkan kesadaran masyarakat tentang kebutuhan dan hak mereka berpartisipasi dalam proses perencanaan dan pengambilan keputusan publik. Kegiatan utama berupa pendampingan, pelatihan serta kampanye publik.

b. Advokasi Kebijakan (Policy Advocacy)

1) Membangun legal framework berupa kebijakan dan peraturan yang mendorong partisipasi.

2) Memberikan insentif/penghargaan terhadap inovasi untuk mendorong partisipasi.

3) Mendorong terbentuknya berbagai partnership antara Pemerintah dengan komponen civil society dengan jalan mendesain dan melakukan uji coba proyek-proyek inovatif dan partisipatif.

4) Memantau program/proyek pemerintah khususnya yang mengandung 
komponen partisipasi.

5) Mempengaruhi kebijakan dan strategi lembaga-lembaga donor internasional tentang partisipasi dan governance. Caranya antara lain dengan aktif terlibat dalam proses konsultasi yang dilakukan berbagai lembaga donor ketika melakukan policy dan strategi bantuannya. Cara lain adalah melakukan pemantauan proyek pembangunan yang dibiayai lembaga keuangan.

c. Pengembangan Institusi (Institution Building)

1) Mendorong terbentuknya Forum Tata Ruang sebagai wujud konsultasi publik.

2) Memperbaiki kualitas partisipasi antara lain dengan menjamin keterlibatan kelompok perempuan dan kelompok marjinal lainnya dalam proses partisipasi

3) Memperkuat jaringan antar-NGOs di daerah agar terjadi shared learning antar-institusi sehingga menjadi lebih efektif menjalankan perannya mendorong good governance.

4) Memfasilitasi upaya penguatan institusi melalui civil education untuk membangun dan mengembangkan kekuatan serta mengasah keterampilan berpartisipasi secara efektif.

d. Pengembangan Kapasitas ( Capacity Building )

1) Mengembangkan berbagai metode alternatif dan teknik-teknik partisipasi.

2) Menyediakan skilled facilitator untuk memfasilitasi proses partisipasi. Pelatihan untuk Community Organiser (CO) dilakukan oleh banyak lembaga untuk mengkader fasilitator-fasilitator handal.

3) Membangun system informasi dan komunikasi berbagai komunitas (community based development).

4) Melakukan pelatihan penggunaan metode partisipatoris baik untuk aparat pemerintah, aktivis, LSM maupun masyarakat.

Dengan demikian pelibatan masyarakat dalam penataan ruang menjadi sangat relevan dalam rangka menciptakan wilayahnya, yaitu tata ruang yang mengutamakan kepentingan masyarakat dan menciptakan lingkungan yang asri. 
Berdasarkan pada beberapa hal yang telah diuraikan maka beberapa hal pokok yang terkait penataan ruang dalam rangka pelibatan masyarakat sebagai berikut:

1) Penatan ruang yang meliputi perencanaan, pemanfaatan dan pengendalian pemanfaatan ruang mutlak dibutuhkan dalam rangka menjamin hak kepemilikan setiap orang, mewujudkan kesejahteraan dan keadilan sosial dan mengelola perkembangan pembangunan yang terjadi (development growth management)

2) Dalam rangka mewujudkan penyelenggaraan penataan ruang tersebut perlu melibatkan masyarakat dengan pendekatan community driven planning. Dengan pendekatan ini diharapkan:

3) Terciptanya kesepakatan dan aturan main di masyarakat dalam rangka mewujudkan keadilan sosial disebabkan program penataan ruang yang disusun sesuai dengan aspirasinya.

4) Meningkatnya rasa memiliki masyarakat terhadap program pemanfaatan ruang yang sejalan dengan terakomodasinya aspirasi masyarakat dalam program penataan ruang.

5) Mewujudkan masyarakat mandiri yang dapat memenuhi dan mengupayakan pemenuhan kebutuhannya sendiri seiring dengan proses pembelajaran berpartisipasi yang terkandung dalam pendekatan peran serta masyarakat dalam penataan ruang.

6) Meningkatnya legitimasi program pembangunan Kabupaten/Kota karena disepakati secara bersama-sama yang pada akhirnya dapat mewujudkan pembangunan yang berkelanjutan.

7) Dengan meningkatnya peran serta masyarakat dalam Penataan ruang maka good governance dapat diwujudkan yang pada akhirnya semakin meningkatkan efesiensi dan efektifitas pembangunan wilayah. Hal ini terjadi karena penyelenggaraan pembangunan akan lebih bisa dilakukan secara transparan, akuntabel, bermoral dan beretika yang berorientasi pada rakyat.

\section{KESIMPULAN}

Berdasarkan pembahasan penelitiaan maka dapat disimpulkan bawa dalam pembangunan dan tat ruang wilayah perlu di dukung dengan adanya partisipasi 
masyarakat yang transparasi, responsif dan akuntabilitas. Jika ini tidak bersinergi maka akan menjadi hambatan dalam pembangunan.

Untuk mewujudkan partisipasi masyarakat yang sesungguhnya harus diupayakan kerjasama dengan pihak-pihak terkait seperti perguruan tinggi, lembaga swadaya masyarakat (ornop), tokoh masyarakat, dewan perwakilan rakyat, dan pihak-pihak terkait lainnya perlu disinergikan. Strategi yang dilakukan untuk meningkatkan peran masyarakat dapat dilakukan dengan cara: 1)peningkatan Kesadaran (Awareness Raising), 2) Advokasi Kebijakan (Policy Advocacy), 3) Pengembangan Institusi (Institution Building), 4) Pengembangan Kapasitas (Capacity Building). Dengan demikian pelibatan masyarakat dalam penataan ruang menjadi sangat relevan dalam rangka menciptakan wilayahnya, yaitu tata ruang yang mengutamakan kepentingan masyarakat dan menciptakan lingkungan yang asri.

\section{DAFTAR PUSTAKA}

Anonim., 2004. Ekologi Lingkungan Hidup dan Pembangunan. Jakarta : Djambatan.

Sujarto., 1976. Tata Ruang Wilayah Perkotaan. Jakarta : Direktorat Jenderal Pendidikan Tinggi.

Sumaatmadja, Nursid ., 1988. Geografi Pembagunan, Jakarta : Direktorat Jenderal Pendidikan Tingg.

Sugiyono, 2010. Metode peneitian Kualitatif dan Kuanttatif. $R \&$ D. Bandung: Afabeta

PP No. 69 Tahun 1996 tentang “Pelaksanaan hak dan kewajiban, serta bentuk dan tata cara peran serta masyarakat dalam Penataan Ruang

TAP MPR IV/MPR/2000 tentang rekomendasi Kebijakan Dalam Penyelenggaraan Otonomi

UU 32/2004 (UU No. 22 Tahun 1999 dan PP No. 25 Tahun 2000) Tentang Otonomi Daerahaerah

UU No. 24 Tahun 1992 Tentang Penataan Ruang yang di sahkan pada tanggal 13 Oktober 